\title{
ALK Gene Mutation Negative
}

National Cancer Institute

\section{Source}

National Cancer Institute. ALK Gene Mutation Negative. NCI Thesaurus. Code C148090.

A genetic finding indicating that ALK gene mutations have not been detected in a sample. 